\title{
Pengaruh Gaya Kepemimpinan Transformasional dan Motivasi Kerja Pada Perilaku Etis Manajer Koperasi
}

\author{
Ni Kadek Candra Kusuma Dewi ${ }^{1}$ \\ Fakultas Ekonomi dan Bisnis \\ Universitas Udayana, Indonesia \\ Email: candraksmdw@gmail.com
}

\author{
A.A. Gde Putu Widanaputra ${ }^{2}$ \\ Fakultas Ekonomi dan Bisnis \\ Universitas Udayana, Indonesia
}

\begin{abstract}
ABSTRAK
Perilaku etis manajer sangat mempengaruhi keberhasilan suatu organisasi. Namun pada praktiknya, tidak sedikit manajer yang bekerja diluar aturan yang telah ditetapkan sehingga berperilaku tidak etis. Penelitian ini dilakukan untuk memperoleh bukti empiris mengenai pengaruh gaya kepemimpinan transformasional dan motivasi kerja pada perilaku etis manajer koperasi. Penelitian ini dilakukan di 48 koperasi di Kabupaten Tabanan. Pengumpulan data dilakukan dengan cara penyebaran kuesioner. Teknik analisis yang digunakan adalah regresi linier berganda. Berdasarkan hasil penelitian ini menunjukkan bahwa gaya kepemimpinan transformasional tidak berpengaruh terdahap perilaku etis manajer koperasi. Motivasi kerja memiliki pengaruh positif signifikan terhadap perilaku etis manajer koperasi yang berarti semakin tinggi motivasi kerja manajer maka semakin tinggi perilaku etis manajer koperasi.
\end{abstract}

Kata Kunci: Gaya Kepemimpinan Transformasional; Motivasi Kerja; Perilaku Etis Manajer Koperasi.

The Effect of Transformational Leadership Styles and Work Motivation on the Ethical Behavior of Cooperative Managers

\begin{abstract}
The ethical behavior of managers greatly influences the success of an organization. But in practice, not a few managers who work outside the rules that have been set so that it behaves unethically. This research was conducted to obtain empirical evidence regarding the influence of transformational leadership styles and work motivation on the ethical behavior of cooperative managers. This research was conducted in 48 cooperatives in Tabanan Regency. Based on the results of this study indicate that the transformational leadership style has a significant insignificant positive effect on the ethical behavior of cooperative managers, which means that transformationalleadership styles are not able to influence the ethical behavior of cooperative managers. Work motivation has a significant positive effect on the ethical behavior of cooperative managers, which means that the higher the work motivation of managers, the higher the ethical behavior of cooperative managers.

Keywords: $\quad$ Transformational Leadership Style; Work Motivation; Manager Ethical Behavior.
\end{abstract}

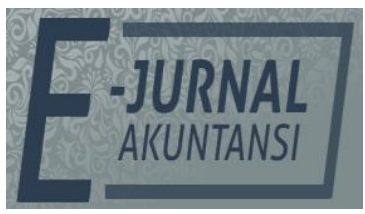

E-JA

e-Jurnal Akuntansi e-ISSN 2302-8556

Vol. 30 No. 7

Denpasar, Juli 2020 Hal.1712-1724

Artikel Masuk: 23 Februari 2020

Tanggal Diterima: 10 Juli 2020

The Article is Available in: https://ojs.unud.ac.id/index.php/Akuntansi/index 


\section{PENDAHULUAN}

Sumber daya manusia memiliki peranan penting dalam sebuah organisasi apapun jenis organisasinya dimana setiap individu memiliki sifat yang beragam. Peran sumber daya manusia (SDM) dalam organisasi koperasi adalah hal yang sangat penting, untuk mencapai tujuan koperasi maka perlu perangkat organisasi yang mampu mengelola kegiatan koperasi. Koperasi memerlukan sumber daya manusia yang handal dan terlatih, namun tidak semua sumber daya manusia yang handal dan terlatih dapat berperilaku etis. Dalam kenyataannya, tidak sedikit manajer yang bekerja diluar aturan yang telah ditetapkan. Tetapi disisi lain adapula karyawan yang sudah bekerja sesuai dengan noorma atau aturan yang berlaku.

Perilaku etis merupakan perbuatan moral yang bisa menunjukkan perilaku 'baik' atau 'benar' sebagai kebalikan dari perilaku yang bersifat 'buruk' ataupun 'salah' pada peraturan yang telah ditetapkan ditetapkan (Cremer \& Dick, 2011). Perilaku etis manajer merupakan interaksi manajer terhadap organisasi dengan mengikuti prinsip-prinsip dan nilai-nilai moral yang berlaku (Skinner \& Ferrell, 2010). Simons (1999) menyatakan bahwa perilaku etis merupakan tingkat kesesuaian antara nilai-nilai yang berlaku dan dianut dengan perilaku individu. Perilaku tidak etis yang dilakukan manajer tentu dapat merugikan organisasi dan dapat merusak citra organisasi. Terjadinya pelanggaran dan kecurangan yang menimbulkan krisis etika dan menyebabkan profesionalisme dan perilaku etis manajer menjadi krisis kepercayaan. Krisis kepercayaan ini diketahui dengan maraknya kasus pelanggaran etika yang melibatkan manajer koperasi.

Salah satu kasus yang mencerminkan adanya perilaku tidak etis dalam organisasi koperasi di Indonesia, yaitu penggelapan dana Lembaga Pengelola Dana Bergulir (LPDB) KUMKM Kementerian Koperasi dan UKM senilai Rp. 3 miliar dengan tersangka yaitu Ketua beserta pengurus koperasi Mega Kharisma Kejari Sinjai Makassar. Dana LPDB yang disalurkan kepada nasabah hanya senilai Rp. 100 juta, dan selebihnya tidak diberikan. Sehingga total dana yang mereka korupsi jumlahnya mencapai Rp. 3 miliar beserta dengan bunganya (Tribunbali.com, 2018).

Kasus lainnya terjadi di Kabupaten Tabanan dimana 3 koperasi dengan nama KSP Maha Suci, KSP Maha Mulia Mandiri, dan KSP Tirta Rahayu. 3 koperasi yang belum legal (mengantongi badan hukum) ini melakukan penggelapan dana nasabah. Koperasi ini bahkan telah berhasil menghimpun dana ratusan milyar dari masyarakat Tabanan. Ketiga koperasi tidak mampu memberikan bunga deposito sesuai kesepakatan dan bahkan uang nasabah yang berhasil dihimpun terancam tidak dikembalikan. Kasus ini pun masih dalam tahap mediasi (Beritabali.com, 2017).

Kasus tersebut menunjukkan bahwa penyimpangan pengelolaan keuangan telah terjadi yang mencerminkan adanya perilaku tidak etis dalam pengelolaan koperasi. Hal ini disebabkan karena rendahnya etika dan moral dari pihak-pihak pembuat keputsan maupun manajer koperasi. Nilai etika yang baik dapat meminimalisir adanya penyimpangan perilaku dalam organisasi. Dengan penerapan etika dan perilaku secara etis diharapkan mampu mengarahkan manajer dalam mengatur hidupnya agar tetap berada dikoridor dan sesuai 
dengan aturan ataupun normayang telah ditetapkan baik berdasarkan aturan tertulis maupun kesepakatan normatif. Peraturan yang dibuat oleh organisasi dapat dijadikan penentu atau pedoman bagi seorang manajer apakah manajer tersebut dapat dikategorikan sebagai manajer yang memiliki sikap etis atau tidak etis.

Penerapan perilaku etis erat kaitannya dengan kepemimpinan pada perusahaan. Keberhasilan dalam mengelola suatu organisasi tidak lepas dari faktor kepemimpinan dan sikap bawahan melaksanakan tugas mencapai tujuan organisasi. Perilaku etis merupakan pusat dari kepemimpinan karena adanya hubungan yang alami antara individu yaitu pemimpin dan pengikutnya (Shleifer, 2014). Pemimpin merupakan pengawas dan pengelola sumber daya yang dimiliki perusahaan agar tujuan perusahaan dapat tercapai. Dunk (2013) menyatakan bahwa pemimpin dapat mempengaruhi kehidupan pengikutnya baik ke arah negatif maupun positif. Kepemimpinan merupakan faktor penting dalam memberikan pengarahan kepada karyawan, terutama dalam melakukan pekerjaannya. Untuk itu manajemen perusahaan harus mampu memilih pemimpin yang memiliki gaya kepemimpinan yang dapat bekerja sama dan dapat menekan kemungkinan terjadinya konflik karyawan dalam bekerja.

Teori atribusi menjelaskan bahwa perilaku individu disebabkan oleh atribut penyebab yaitu ditentukan oleh kombinasi antara kekuatan internal (internal forces), yaitu faktor-faktor yang berasal dari dalam diri seseorang dan kekuatan eksternal (eksternal forces). Kepemimpinan merupakan salah satu faktor eksternal yang dapat mempengaruhi perilaku manajer. Berhasil atau tidaknya sebuah organisasi sangat ditentukan oleh kepemimpinan, karena pemimpin bertanggungjawab atas kegagalan pelaksanaan pekerjaan, sebaliknya kesuksesan dalam memimpin sebuah organisasi merupakan keberhasilan seseorang mempengaruhi orang lain untuk menggerakkan atau menjalankan visinya, selain itu adanya koordinasi atau kerjasama yang baik antara pimpinan dan bawahannya.

Salah satu gaya kepemimpinan yang sesuai dalam menghadapi segala perubahan dan meningkatkan sikap pro aktif karyawan adalah gaya kepemimpinan transformasional. Bass \& Avolio (1987) menjelaskan bahwa pemimpin transformasional menciptakan perubahan signifikan baik terhadap pengikutnya maupun terhadap organisasi. Pemimpin transformasional merupakan seorang agen perubahan yang berusaha keras melakukan transformasi ulang organisasi secara menyeluruh sehingga organisasi bisa mencapai kinerja yang lebih maksimal di masa depan. Wardana (2016) menyatakan bahwa kepemimpinan transformasional adalah sebuah proses dimana para pemimpin dan pengikut saling meningkatkan diri ke moralitas dan motivasi yang lebih tinggi. Tingkat sejauh mana seorang pemimpin disebut transformasional dapat diukur dalam hubungannya dengan efek pemimpin tersebut terhadap bawahan (Zhu \& Avolio, 2014).

Torisa Utami (2010) menyatakan gaya kepemimpinan transformasional berpengaruh terhadap perilaku karyawan. Penelitian lainnya dilakukan Nariswari \& Rahardjo (2016) memperoleh hasil gaya kepemimpinan transformasional memiliki pengaruh yang positif dan signifikan terhadap 
kepuasan kerja karyawan. Ketika kepuasan kerja karyawan meningkat maka semakin rendah perilaku tidak etisnya. Dalam penelitian Wardana (2016) gaya kepemimpinan transformasional seorang auditor akan menghasilkan kualitas audit yang baik.

Kepemimpinan transformasional mampu menggerakkan manajer dalam mencapai tujuan yang telah ditetapkan karena pengaruh kewibawaan pemimpinnya, selain itu mampu menciptakan motivasi dalam diri setiap karyawan maupun pimpinan itu sendiri . Dengan penerapan gaya kepemimpinan transformasional yang baik dapat meningkatkan perilaku etis manajernya. Dari uraian sebelumnya maka dapat dikembangkan hipotesis penelitian sebagai berikut:

$\mathrm{H}_{1}$ : Semakin tinggi tingkat kepemimpinan transformasional dalam koperasi, maka semakin tinggi perilaku etis manajer.

Agar perilaku tidak etis tidak terjadi dalam organisasi, maka manajemen juga harus dapat memotivasi manajer dalam bekerja. Motivasi merupakan hasil sejumlah proses yang bersifat internal atau eksternal bagi setiap individu dalam melaksanakan kegiatan-kegiatannya (Indra Putra, 2015). Teori kebutuhan Maslow mengemukakan jika kebutuhan manajer harus dipenuhi agar dapat termotivasi untuk bekerja. Manajer yang kebutuhannya tidak terpenuhi akan menunjukkan perilaku kecewa salah satunya dengan berperilaku tidak sesuai aturan perusahan atau berperilaku tidak etis. Dengan adanya motivasi yang dimiliki setiap individu, maka secara tidak langsung akan mempengaruhi perilaku dalam bekerja. Motivasi yang ada pada diri seseorang akan mewujudkan suatu perilaku yang diarahkan pada tujuan mencapai sasaran kepuasan dan motivasi bukanlah perilaku yang kelihatan. Sehingga pemimpin harus dapat memotivasi manajer agar mau melaksanakan pekerjaan sesuai dengan kecakapan yang mereka miliki dan diharapkan mereka tidak hanya asal mau bekerja.

Motivasi terbentuk dari sikap (attitude) karyawan dalam menghadapi situasi kerja diperusahaan (situation). Motivasi merupakan sikap atau tindakan dari sebuah kegigihan dan arahan yang mengarah pada pencapaian suatu tujuan Dwi \& Candra (2015). Motivasi sebagai proses psikologis dalam diri seseorang akan dipengaruhi oleh beberapa faktor. Motivasi merupakan kondisi yang menggerakan diri manajer yang terarah atau tertuju untuk mencapai tujuan organisasi perusahaan. Sikap mental manajer yang pro dan positif terhadap situasi kerja itulah yang memperkuat motivasi kerjanya untuk mencapai kinerja maksimal. Simons (1999) mengungkapkan faktor-faktor tersebut dapat dibedakan menjadi dua yaitu: faktor internal, yang berasal dalam diri karayawan yaitu keinginan untuk dapat hidup, keinginan untuk dapat memiliki, keinginan untuk memperoleh penghargaan, dan keinginan untuk memperoleh pengakuan. Faktor Eksternal, yang berasal dari luar diri karyawan antara lain kondisi lingkungan kerja, kompensasi yang memadai, suprevisi yang baik, adanya jaminan pekerjaan serta status dan tanggung jawab.

Hasil penelitian Dwi \& Candra (2015) memperoleh hasil bahwa terdapat pengaruh yang signifikan antara motivasi dan perilaku etis auditor junior. Penelitian lainnya dilakukan oleh Bellyanti (2016) menyatakan motivasi individu yang kurang akan membuat individu berperilaku cenderung tidak etis. Nababan, 
(2017) meneliti tentang pengaruh motivasi kerja terhadap perilaku etis karyawan pada sistim penggajian dengan gaya kepemimpinan sebagai variable moderasi dan memperoleh hasil bahwa motivasi yang diberikan oleh pimpinan berpengaruh positif terhadap perilaku etis karyawan.

Motivasi yang diberikan dari pihak manajemen organisasi dengan porsi yang tepat akan membuat manajer merasa diperhatikan dan nyaman dalam menjalankan pekerjaannya, serta dapat bekerja sesuai standar operasional yang berlaku pada organisasi. Semakin tinggi motivasi yang dimiliki seseorang maupun yang motivasi yang diberikan oleh manajemen perusahaan kepada manajernya, maka semakin rendah perilaku tidak etis atau dengan kata lain dapat tercipta perilaku yang baik atau etis. Motivasi dari dalam diri seseorang maupun motivasi dari luar diri seseorang yang baik dan kuat dapat menciptakan perilaku etis sehingga dapat mendukung kinerja seseorang yang juga berdampak pada peningkatan omset perusahaan. Dari uraian sebelumnya maka dapat dikembangkan hipotesis penelitian sebagai berikut:

$\mathrm{H}_{2}$ : Semakin tinggi motivasi kerja, maka semakin tinggi perilaku etis manajer koperasi.

\section{METODE PENELITIAN}

Penlitian ini dilakukan di Koperasi di Kabupaten Tabanan. Objek dalam penelitian ini adalah perilaku etis prgawai koperasi. Data yang digunakan dalam penelitian ini adalah data kuantitatif. Data kuantitatif dalam penelitian ini diperoleh dengan menggunakan hasil scoring dari jawaban para responden terhadap kuesioner yang telah dibagikan. Penelitian ini menggunakan data primer yaitu data yang diperoleh secara langsung dari subjek penelitian sebagai sumber informasi yang dicari. Instrumen yang digunakan dalam penelitian ini berupa kuesioner. Pengukuran dilakukan menggunakan Skala Likert 5 poin. Skor 5 menandakan jawaban sangat setuju (SS), skor 4 menandakan jawaban setuju (S), skor 3 menandakan jawaban netral (N), skor 2 menandakan jawaban tidak setuju (TS), dan skor 1 menandakan jawaban sangat tidak setuju (STS).

Populasi dalam penelitian ini adalah manajer koperasi yang bekerja di 378 koperasi di Kabupaten Tabanan yaitu sebanyak 3.024 orang manajer. Penelitian ini menggunakan teknik purposive sampling yaitu pemilihan sampel didasarkan pada kriteria dan sistematika tertentu yang telah ditetapkan sebelumnya. Total sampel yang memenuhi kriteria dalam penelitian ini adalah 48 orang manajer koperasi simpan pinjam di Kabupaten Tabanan.

Adapun kriteria-kriteria yang digunakan untuk pengambilan sampel dalam penelitian ini antara lain: Koperasi Simpan Pinjam di Kabupaten Tabanan yang melaksanakan RAT, Koperasi Simpan Pinjam di Kabupaten Tabanan yang berdiri minimal 5 tahun.

Sampel penelitian adalah seluruh manajer koperasi yang sesuai kreteria tersebut. Dari sampel yang ada dipilih responden yaitu manajer yang menduduki jabatan minimal 1 tahun.

Teknik analisis yang digunakan dalam penelitian ini adalah regresi linier berganda. Analisis ini digunakan untuk mengetahui arah dan besarnya pengaruh dari variabel bebas yang akan diteliti yaitu digunakan untuk mengukur gaya kepemimpinan transformasioanl dan motivasi kerja pada 
perilaku tidak etis manajer. Model regresi linier berganda dalam penelitian ini disajikan dalam persamaan berikut:

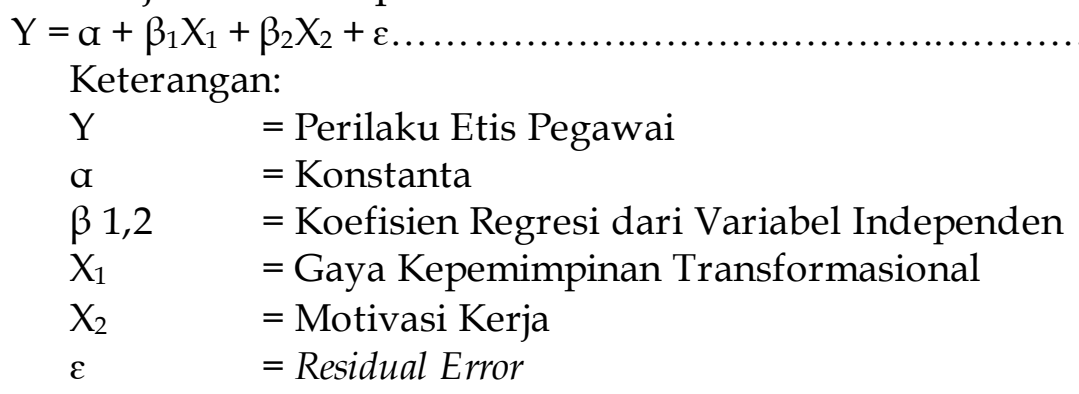

Analisis statistik deskriptif bertujuan untuk memberikan gambaran suatu data yang dapat dilihat dari nilai rata-rata (mean), nilai minimum, nilai maksimum dan standar nilai deviasi dari data penelitian yang diperoleh dari jawaban responden (Widyasari \& Suardikha, 2015). Uji normalitas bertujuan untuk mengetahui apakah data yang digunakan dalam penelitian ini berdistribusi normal atau tidak, uji normalitas akan dilakukan dengan menggunakan Uji Kolmgorov-Smirnov (K-S), yaitu dengan melihat nilai signifikansinya. Uji multikolinearitas dilakukan dengan tujuan apakah dalam model regresi ditemukan adanya kolerasi antar variabel bebas. Uji multikolinearitas jika menunjukkan tolerance $>0,01$ dan nilai VIF $<10$ untuk semua variabel bebas, maka dapat dikatakan bahwa tidak terdapat multikolinearitas antar variabel bebas dalam model regresi (Gunawan \& Tenaya, 2017). Uji heteroskedasitas digunakan untuk mengukur sama atau tidaknya variance dari residual observasi satu dengan observasi lainnya. Jika residual mempunyai variance yang sama disebut homoskedastisitas dan jika variance tidak sama disebut heteroskedastisitas.

Uji kelayakan model bertujuan untuk menguji apakah model yang digunakan dalam penelitian ini layak untuk diguakan atau tidak sebagai model regresi. Apabila tingkat signifikansi $\mathrm{F}<\mathrm{a}=0,05$ maka dapat dikatakan bahwa model dalam penelitian ini layak untuk digunakan.

Analisis koefisien determinasi bertujuan untuk mengetahui seberapa besar kemampuan variabel independen menjelaskan variabel dependen (Ghozali, 2016). Dalam output SPSS, koefisien determinasi terletak pada variabel Model Summary dan tertulis $R$ Square. Nilai $R$ Square dinyatakan baik jika 0,5 karena $\mathrm{R}$ Square berkisar antara 0 sampai 1 . Uji hipotesis secara parsial dilakukan dengan uji statistik t. Jika nilai signifikansi < 0,05 maka Ho ditolak, berarti terdapat pengaruh antara variabel bebas dengan variabel terikat secara parsial.

\section{HASIL DAN PEMBAHASAN}

Karakteristik responden merupakan profil dari 48 responden yang berpartisipasi dalam pengisian kuesioner penelitian ini. Data karakteristik responden meliputi jenis kelamin, usia, lama masa bekerja dan jenjang pendidikan terakhir. Responden dengan jenis kelamin laki-laki sebesar 94 persen sedangkan responden perempuan sebesar 6 persen. Hal tersebut menunjukkan manajer yang bekerja di Koperasi Simpan Pinjam Kabupaten Tabanan hampir seluruhnya 
didominasi oleh laki-laki. Karakteristik responden berdasarkan tingkat usia menunjukan persentase jumlah responden yang berusia 20-30 tahun adalah 4 persen, responden yang berusia 31-40 tahun 23 persen dan responden yang berusia lebih dari 40 tahun 73 persen. Hal tersebut menunjukan bahwa rata-rata usia manajer koperasi di Kabupaten Tabanan berada di rentang usia lebih dari 40 tahun. Karakteristik responden berdasarkan lama masa bekerja menunjukan rata-rata manajer koperasi di Kabupaten Tabanan sudah bekerja selama 6-10 tahun. Karakteristik responden berdasarkan tingkat pendidikan terakhir menunjukan sebagian besar respoden memiliki pendidikan terakhir yaitu Sarjana.

Hasil uji validitas menunjukkan bahwa setiap item pertanyaan dari masing- masing variabel perilaku etis manajer $(\mathrm{Y})$, gaya kepemimpinan transformasional $\left(X_{1}\right)$ dan motivasi kerja $\left(X_{2}\right)$ pada kuesioner memiliki nilai koefisien korelasi lebih besar dari 0,3, sehingga pertanyaan dalam kuesioner yang digunakan dinyatakan valid atau telah memenuhi syarat validitas data.

Hasil uji reliabilitas menunjukan nilai Cronbach's Alpha masing-masing variabel pada kuesioner meliputi variabel perilaku etis manajer $(Y)$ sebesar 0,787, gaya kepemimpinan transformasional $\left(X_{1}\right)$ sebesar 0.810 dan motivasi kerja $\left(X_{2}\right)$ sebesar 0,716. Variabel dengan Nilai Cronbach's Alpha lebih besar dari 0,7 maka dapat disimpulkan bahwa kuesioner yang digunakan sudah reliabel.

Tabel 1. Hasil Analisis Statistik Deskriptif

\begin{tabular}{llllll}
\hline Variabel & $\mathrm{N}$ & Minimum & Maksimum & Mean & $\begin{array}{l}\text { Std. } \\
\text { Deviation }\end{array}$ \\
\hline $\begin{array}{l}\text { Perilaku Etis Pegawai } \\
(Y)\end{array}$ & 48 & 39.00 & 50.00 & 45.1458 & 2.73659 \\
$\begin{array}{l}\text { Gaya Kepemimpinan } \\
\left(X_{1}\right)\end{array}$ & 48 & 60.00 & 80.00 & 68.3125 & 4.66383 \\
Motivasi Kerja (X2) & 48 & 24.00 & 30.00 & 26.4375 & 1.77340 \\
\hline
\end{tabular}

Sumber : Data Penelitian, 2019

Statistik deskriptif memberikan informasi mengenai karakteristik variable penelitian yang terdiri atas jumlah pengamatan, nilai minimum, nilai maksimum, nilai mean, dan standar deviasi. Variabel perilaku etis manajer (Y) memperoleh nilai minimum adalah 39 dan nilai maksimumnya adalah 50 . Nilai rata-rata sebesar 45,1458. Standar deviasi sebesar 2,73659, berarti perbedaan tingkat perilaku etis manajer yang diteliti terhadap nilai rata-ratanya sebesar 2,73659. Variabel gaya kepemimpinan transformasional $\left(X_{1}\right)$ memperoleh nilai minimum yaitu 60 dan nilai maksimumnya adalah 80. Nilai rata-rata sebesar 68,3125 , dan standar deviasi sebesar 4,66383. Variabel motivasi kerja $\left(\mathrm{X}_{2}\right)$ nilai minimumnya adalah 24 dan nilai maksimumnya adalah 30 . Nilai rata-rata sebesar 26,4375 dan tandar deviasi sebesar 1,77340.

Tabel 2. Hasil Uji Normalitas

\begin{tabular}{lc}
\hline Kolmgorov-Smirnov Z & Unstandarized Residual \\
\hline $\mathrm{N}$ & 48 \\
Asymp.Sig. (2-tailed) & 0,200 \\
\hline
\end{tabular}

Sumber: Data Penelitian, 2019

Hasil uji normalitas menunjukkan bahwa nilai Asymp. Sig. (2-tailed) yang dihasilkan adalah sebesar 0,200. Nilai yang dihasilkan ini lebih besar dari 
signifikan 0,05 sehingga dapat disimpulkan bahwa data telah terdistribusi normal.

Tabel 3. Hasil Uji Multikolinearitas

\begin{tabular}{|c|c|c|}
\hline Variabel & Tolerance & VIF \\
\hline Gaya $\quad$ Kepemimpinan & 0,615 & 1,627 \\
\hline Motivasi Kerja $\left(X_{2}\right)$ & 0,615 & 1,627 \\
\hline
\end{tabular}

Sumber: Data Penelitian, 2019

Hasil uji multikolonieritas menunjukkan bahwa untuk semua variabel independen yang digunakan memiliki nilai tolerance lebih besar dari 0,1 yaitu, gaya kepemimpinan transformasional $\left(X_{1}\right)$ sebesar 0,615 dan motivasi kerja $\left(X_{2}\right)$ sebesar 0,615 . Nilai VIF yang dihasilkan kurang dari 10, gaya kepemimpinan transformasional $\left(X_{1}\right)$ sebesar 1,627 dan motivasi kerja $\left(X_{2}\right)$ sebesar 1,627 sehingga dapat disimpulkan bahwa tidak terjadi korelasi ganda (multikolinieritas) antar variabel bebas.

Tabel 4. Hasil Uji Heteroskedastisitas

\begin{tabular}{clc}
\hline Variabel & Signifikansi & Keterangan \\
\hline Gaya Kepemimpinan & 0,081 & Bebas \\
Transformasional $\left(\mathrm{X}_{1}\right)$ & 0,087 & $\begin{array}{c}\text { Heteroskedastisitas } \\
\text { Bebas }\end{array}$ \\
Motivasi Kerja $\left(\mathrm{X}_{2}\right)$ & Heteroskedastisitas \\
\hline
\end{tabular}

Sumber : Data Penelitian, 2019

Dari hasil uji heteroskedastisitas diketahui bahwa semua variabel bebas yang digunakan pada penelitian yaitu, gaya kepemimpinan transformasional $\left(X_{1}\right)$ sebesar dengan signifikansi 0,081 dan motivasi kerja (X2) dengan signifikansi sebesar 0,087 memiliki nilai lebih besar dari 0,05 sehingga dapat disimpulkan bahwa tidak terjadi gejala heterokedasitas.

Tabel 5. Hasil Regresi Berganda

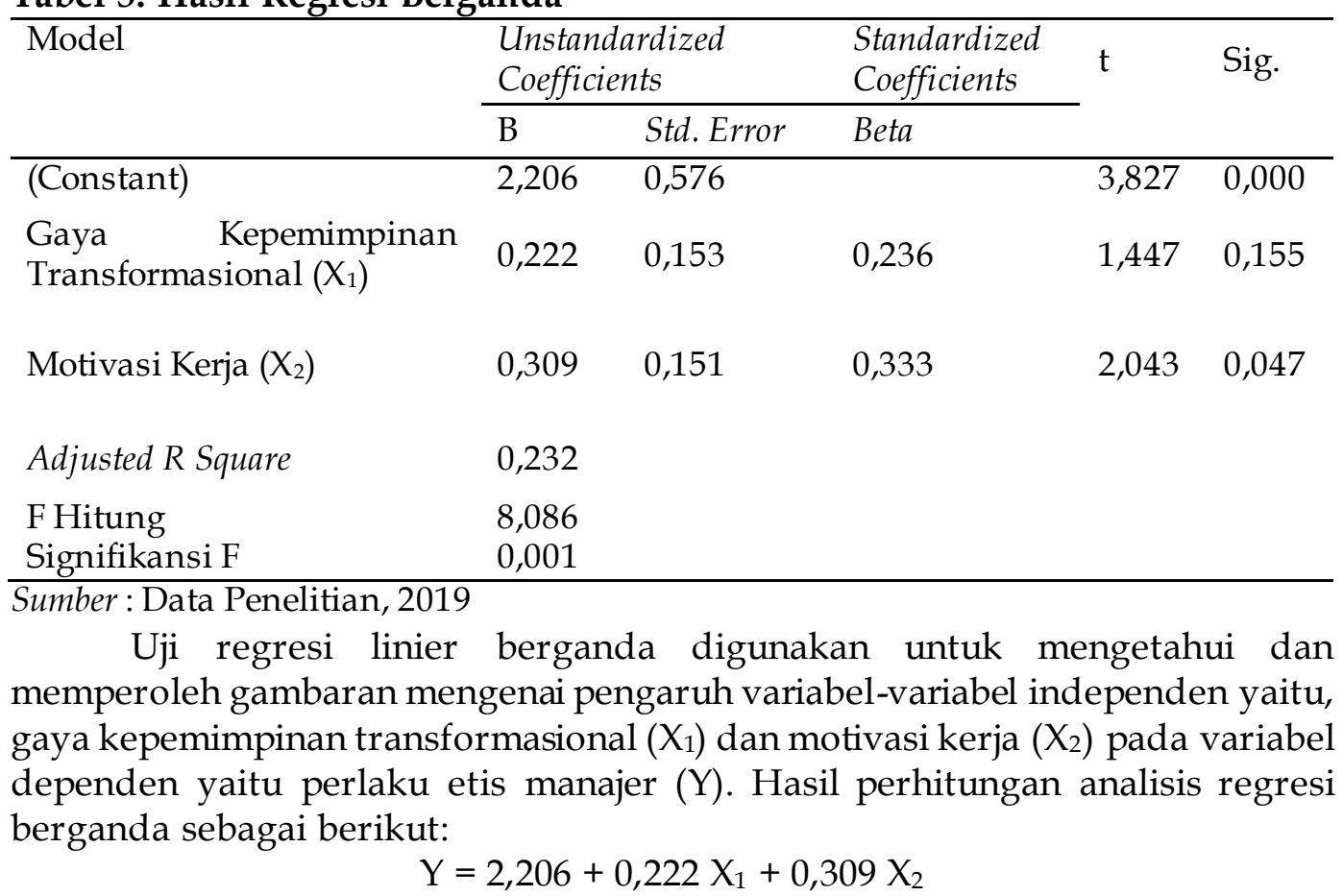


Nilai konstanta benilai positif sebesar 2,206 maka dapat diartikan apabila tidak terdapat pengaruh dari variabel lain atau variable bebas, maka nilai konstan dari perilaku etis manajer (Y) adalah sebesar 2,206. Nilai koefisien variabel gaya kepemimpinan transformasional $\left(X_{1}\right)$ bernilai positif sebesar 0,222 maka artinya apabila nilai gaya kepemimpinan transformasional $\left(\mathrm{X}_{1}\right)$ naik satu satuan dengan asumsi bahwa variabel lainnya konstan, maka perilaku etis manajer (Y) akan naik sebesar 0,222. Nilai koefisien variabel motivasi kerja $\left(\mathrm{X}_{2}\right)$ bernilai positif sebesar 0,309 maka artinya apabila nilai motivasi kerja $\left(\mathrm{X}_{2}\right)$ naik satu satuan dengan asumsi bahwa variabel lainnya konstan, maka perilaku etis manajer (Y) akan naik sebesar 0,309.

Nilai dari Adjusted $\mathrm{R}^{2}$ adalah sebesar 0,232 atau 23,2 persen. Hal ini menandakan bahwa sebesar 23,3 persen variansi perilaku etis manajer dapat dipengaruhi oleh variabel gaya kepemimpinan transformasional dan motivasi kerja, sedangkan sisanya sebesar 76,8 persen dijelaskan oleh faktor-faktor lain yang tidak dijelaskan dalam model penelitian ini.

Nilai F hitung sebesar 8,086. Nilai F hitung ini lebih besar dari nilai F table sebesar 3,20 dan signifikansi uji $\mathrm{F}$ adalah sebesar 0,001 yang lebih kecil dari 0,05. Hal tersebut menandakan bahwa variabel gaya kepemimpinan transformasional dan motivasi kerja tepat menjelaskan fenomena perilaku etis manajer.

Nilai tingkat signifikansi $\mathrm{t}$ untuk variabel gaya kepemimpinan transformasional adalah sebesar 0,155 atau $t=0,155>0,05$. Hal ini mengindikasikan bahwa tidak terdapat pengaruh signifikan secara parsial antara gaya kepemimpinan transformasional $\left(\mathrm{X}_{1}\right)$ terdahap perilaku etis manajer $(\mathrm{Y})$. Nilai tingkat signifikansi t untuk variabel motivasi kerja adalah sebesar 0,047 atau $\mathrm{t}=0,047<0,05$. Hal ini mengindikasikan bahwa terdapat pengaruh signifikan secara parsial antara motivasi kerja $\left(\mathrm{X}_{2}\right)$ terdahap perilaku etis manajer $(\mathrm{Y})$.

Maka Gaya kepemimpinan transformasional $\left(\mathrm{X}_{1}\right)$ tidak berpengaruh terdahap perilaku etis manajer (Y). Dalam teori atribusi disebutkan bahwa manusia bertindak disebabkan oleh faktor eksternal dan internal. Gaya kepemimpinan transformasional merupakan faktor eksternal yang mempengaruhi individu dalam berperilaku etis, namun dalam penelitian ini pengaruh gaya kepemimpinan transformasional tidak signifikan terhadap perilaku etis. Dalam penelitian rata-rata hasil pernyataan responden pada variabel gaya kepemimpinan transformasional sebesar 68,3125 yang berarti netral namun cenderung setuju sehingga dapat disimpulkan bahwa manajer cenderung merasakan adanya interaksi pemimpin dan manajer untuk mengubah perilaku manajer menjadi seorang yang merasa mampu, bermotivasi tinggi dan berupaya mencapai prestasi namun merasa tidak mempengaruhinya sehingga perilaku yang timbul cenderung berasal dari individu manajer itu sendiri atau dari faktor intern.

Faktor intern yang mempengaruhi perilaku individu sehingga dapat berperilaku etis adalah moralitas dan idealisme. Sesuai dengan teori perkembangan moral Kohlberg dalam penelitian Bellyanti (2016) disimpulkan bahwa level penalaran moral individu akan mempengaruhi perilaku etis mereka. Seseorang dapat dikatakan bermoral jika tindakan dan perilakunya 
mencerminkan moralitas, dalam arti orang tersebut dapat membedakan mana hal yang baik dan buruk. Penelitian lainnya diakukan oleh Pandhu Prabowo (2018) mendapatkan bukti adanya sifat individu yang memengaruhi perilaku etis. Individu yang idealis akan menghindar dari tindakan yang membawa kerugian bagi orang-orang sekitar dan mereka tidak akan bertindak yang memiliki konsekuensi negatif, dimana dalam setiap langkah yang diambil menunjukkan keberpihakan kepada nilai moral pada masyarakat dan tidak melanggar nilai-nilai yang berlaku tersebut.

Motivasi kerja $\left(\mathrm{X}_{2}\right)$ memiliki pengaruh positif signifikan terhadap perilaku etis manajer $(Y)$. Hasil penelitian ini sejalan dengan hasil penelitian terhadulu yang telah dilakukan oleh Dwi \& Candra (2015), Bellyanti (2016), dan Nababan, (2017) yang menyatakan bahwa motivasi kerja berpengaruh positif terhadap perilaku etis manajer.. Hasil penelitian tersebut mendukung teori Atribusi yang menyatakan bahwa perilaku manajer disebabkan oleh atribut penyebab yaitu kombinasi antara kekuatan internal dan kekutan eksternal. Motivasi yang diberikan pimpinan maupun yang timbul dari dalam diri individu sendiri menciptakan sikap mental manajer yang pro dan positif terhadap situasi kerja itulah yang memperkuat motivasi kerjanya dan berperilaku sesuai peraturan dan nilai-nilai organisasi untuk mencapai kinerja maksimal. Dalam teori kebutuhan Maslow disebutkan bahwa jika kebutuhan manajer terpenuhi maka manajer akan memperlihatkan perilaku yang senang sebagai bentuk dari rasa puasnya. Motivasi yang diberikan pimpinan berupa kepercayaan dalam bekerja, penghargaan, promosi jabatan, serta motivasi untuk bekerjasama dengan bawahan antar teman kerja membuat manajer merasa diperhatikan dan nyaman dalam menjalankan pekerjaannya, serta dapat bekerja sesuai standar operasional yang berlaku pada organisasi. Semakin tinggi motivasi yang dimiliki seseorang maupun yang motivasi yang diberikan oleh manajemen perusahaan kepada manajer maka semakin tinggi perilaku etis manajernya.

\section{SIMPULAN}

Semakin tinggi motivasi kerja manajer maka semakin tinggi perilaku etis manajer. Dorongan dari dalam diri manajer maupun dari pimpinan memunculkan sikap mental manajer yang pro dan positif terhadap situasi kerja sehingga manajer bekerja sesuai standar operasional dan menciptakan perilaku etis manajer. Sementara itu, gaya kepemimpinan transformasional berpengaruh positif tidak signifikan terhadap perilaku etis manajer. Manajer cenderung merasakan adanya interaksi pemimpin dan manajer untuk mengubah perilaku manajer menjadi seorang yang merasa mampu, bermotivasi tinggi dan berupaya mencapai prestasi namun merasa tidak mempengaruhinya. Hal tersebut dapat terjadi karena faktor intern seperti moralitas dan idialisme yang lebih besar dalam mempengaruhi perilaku etis manajer.

Bagi Pimpinan Koperasi di Kabupaten Tabanan diharapkan dapat memberikan motivasi yang lebih intensif sehingga manajer terdorong untuk bersikap positif yang menciptakan perilaku etis manajer. Bagi peneliti selanjutnya yang tertarik untuk melakukan penelitian serupa, disrankan agar 
melakukan perluasan penelitian dengan menambahkan atau mengganti variabel yang mungkin berpengaruh pada perilaku etis manajer.

\section{REFERENSI}

Ananto, R. (2014). Analisis Pengaruh Gaya Kepemimpinan, Motivasi dan Disiplin Kerja Terhadap Kinerja Manajer (Studi Empiris Pada PT DHL Global Forwarding Semarang Branch. Diponegoro Journal of Accounting. 3(2), h:1-9 https://doi.org/10.1080/09638180.2018.1509014

Bass, B. M., \& Avolio, B. J. (1994). Shatter the Glass Ceiling: Women May Make Better Managers. International Journal of Economics and Finance. 33(4), 549560. https://doi.org/10.1111/j.0306-686X.2005.00645.x

Bass, B. M., Waldman, D. A., \& Avolio, B. J. (1987). Transformational Leadership and the Falling Dominoes Effect. International Journal of Economics and Finance. 12(1), 73-87. https://doi.org/10.1016/j.adiac.2010.03.001

Beritabali.com. (2017). Di Bali, 44 LPD Go Digital. Retrieved September 20, 2019, from Beritabali.com website: http://doi.org bisnisbali.com/2017/08/10/dibali-44-lpd-go-digital/

Bellyanti, L. A., \& Rasmini. (2016). Pengaruh Keefektifan Pengendalian Intern, Reward, dan Motivasi Individu pada Perilaku Etis Karyawan (Studi CV. Sinar Dian). Skripsi. Fakultas Ekonomi Dan Bisnis Universitas Udayana. https://doi.org/10.24843/EJA.2019.v28.i03.p21.

Cremer, D. De \& Murnighan, J. K. (2011). Understanding Ethical Behavior and Decision Making in Management: A Behavioural Business Ethics Approach. American Journal of Economics 22. https://doi.org/10.1111/j.14678551.2010.00733.x

Dunk, A. (2013). The Effect Of Budget Emphasis And Information Asymmetry On The Relation Between Budgetary. Accounting Review: A Quarterly Journal of the American Accounting Association, 68(2), 400-410. doi.org/10.33648/ijoaser.v2i2.31

Dwi, Cahyani \& Kadek Candra, D. (2015). Motivasi , Budaya Kerja , Dan Tingkat Pendidikan Terhadap Persepsi Etis Auditor Junior ( Studi Empiris Pada Kantor Akuntan Publik di Bali ). e-Journal S1 Ak Universitas Pendidikan Ganesha. 3(1). 117-127. https://doi.org/10.1016/j.adiac.2010.03.001

Ghozali, H. I. (2016). Aplikasi Analisis Multivariate dengan Program IBM SPSS 21 (Edisi 8; P. P. Harto, Ed.). Semarang: Badan Penerbit Universitas Diponegoro. https://doi.org/10.1108/EBS-07-2012-0035

Honeycutt \& Karande, K. (2011). Determinants of ethical behavior: A study of autosalespeople. Journal of Business Ethics, 32(1), 69-79. https://doi.org/10.1023/A:1010704409683

Indra Putra, B. (2015). Pengaruh Pengendalian Intern, Motivasi dan Reward Manajemen terhadap Perilaku Etis Karyawan ( Studi Kasus PT Inti Sukses Garmindo, Semarang).e-Journal Fakultas Ekonomi dan Bisnis Universitas Dian Nuswantoro Semarang.

Jayanti, I., \& Rasmini (2013). Pengaruh Pengendalian Intern, Motivasi, dan Reward Manajemen Pada Perilaku Etis Konsultan. e-Jurnal Akuntansi Universitas Udayana, 179-195. https://doi.org/10.24843/eja.2018.v24.i01.p03

Kurniawan, H. (2011). Pengaruh Gaya Kepemimpinan Transformasional 
Terhadap Perilaku Etis Karyawan Pt. Berau Karya Indah Di Surabaya Melalui Motivasi Kerja. Airlangga Journal of Management. 8(7): 3314-3322

Leonard, Cronan, et al. (2014). What influences IT ethical behavior intentions Planned behavior, reasoned action, perceived importance, or individual characteristics?. Journal Information and Management, 42(1), 143-158. https://doi.org/10.1016/j.im.2003.12.008

Leroy, H., \& Simons, T. L. (2012). Authentic Leadership and Behavioral Integrity as Drivers of Follower Commitment and Performance Authentic Leadership and Behavioral Integrity as Drivers of Follower. International Journal of Information Management, https://doi.org/10.1111/j.0306-686X.2005.00645.x

Lin, Z. J., \& Liu, M. (2010). The determinants of auditor switching from the perspective of corporate governance in China. Advances in Accounting, 26(1), 117-127. https://doi.org/10.1016/j.adiac.2010.03.001

Maslow, B. A. H., \& Green, C. D. (1943). A Theory of Human Motivation A Theory of Human Motivation. Journal of Applied Sciences Research .1-21.

Nababan, D. (2017). Pengaruh Motivasi Kerja dan Kompensasi Terhadap Perilaku Etis Karyawan dalam Sistem Penggajian dengan Gaya Kepemimpinan sebagai Variabel Moderating. Journal of Faculty of Economic, Universitas Widyatama, Bandung. XXI(02), 306-316.

Nanda, L. (2014). Analisis Pengaruh Motivasi Kerja, Pengendalian Internal, Dan Komitmen Organisasi Terhadap Kinerja Karyawan (Studi Empiris Pada AJB Bumi Putera 1912 Kantor Cabang Solo Gladag). Skripsi. Universitas Muhammadiyah Surakarta. http://dx.doi.org/10.5539/ibr.v5n11p136

Nariswari, L., \& Rahardjo, M. (2016). Analisis Pengaruh Gaya Kepemimpinan Kepuasan Kerja Karyawan ( Studi pada PT . Poliplas Indah Sejahtera ). 5, 110. Diponegoro Journal Of Management. 2337-3792. https://doi.org/10.24843/2016.v28.i03.p21.

Northouse \& Mood,. (2013). Randomized Clinical Trial Of A Brief And Extensive Dyadic Intervention For Advanced Cancer Patients And Their Family Caregivers. Journal of International Accounting, Auditing and Taxation. 563(January 2012), 555-563.

Oghojafor, B. E. A., \& Okonji, P. S. (2012). Attribution Theory and Strategic Decisions on Organizational Success Factors. International Journal of Economics and Finance. 3(1), 32-39. https://doi.org/10.5430/jms.v3n1p32 Pandhu Prabowo, P. \& Widanaputra. (2018). Pengaruh Love Of Money , Machiavellian, dan Idealisme Pada Persepsi Etis Mahasiswa Akuntansi Fakultas Ekonomi dan Bisnis Universitas Udayana ( Unud ), Bali, Indonesia. Skripsi. Fakultas Ekonomi dan Bisnis Universitas Udayana. 23, 513-537. https://doi.org/10.24843/EJA.2019.v28.i03.p21.

Shleifer, A. (2014). Does competition destroy ethical behavior? American EconomicReview,94(2),414-418. https://doi.org/10.1257/0002828041301498

Simons, T. L. (1999). Behavioral Integrity as a Critical Ingredient for Transformational Leadership Behavioral Integrity as a Critical Ingredient for Transformational. The International Journal of Social Sciences and Humanities. 5(10), 5008-5016. https://doi.org/10.18535/ijsshi/v5i10.03

Sina, M. I. (2013). Analisis Pengaruh Gaya Kepemimpinan Transformasional Terhadap Kinerja Karyawan Dengan Komitmen Organisasi Sebagai 
Variabel Intervening. Accounting Analysis Journal Universitas Diponegoro Semarang. https://doi.org/10.1080/09638180.2018.1509014

Skinner, J., \& Ferrell, O. C. (2010). Ethical Behavior and Bureaucratic Structure in Marketing Research Organizations Author(s): 25(1), 103-109. doi.org/10.1080/09638180.2018.1509014

Sugiyono. (2013). Metode Penelitian Kuantitatif, Kualitatif dan RED. Bandung: Alfabeta. doi.org/10.1108/02686900610680512

Sujana, \& Edy. (2012). Pengaruh Kompetensi, Motivasi, Kesesuaian Peran Dan Komitmen Organisasi Terhadap Perilaku Etis Auditor Internal Inspektorat Pemerintah Kabupaten (Studi Pada Kantor Inspektorat Kabupaten Badung Dan Buleleng). Skripsi. Universitas Pendidikan Ganesha. (2), 1-27. doi.org/10.2308/accr.2007.82.3.621

Surbakti, M. P. (2013). Analisis Pengaruh Kepemimpinan Transformasional dan Motivasi Kerja terhadap Perilaku Etis Karyawan (Studi pada PT. Kereta Api Indonesia Daop IV Semarang).Skripsi. Fakultas Ekonomi dan Bisnis Universitas Diponegoro. https://doi.org/10.2308/accr.2003.78.1.95

Tely Sutan, S. (2016). Analisis Keterkaitan Antara Gaya Kepemimpinan Dan Organizational Trust Terhadap Perilaku Etis Pada Pt Samolindo Metal Berjaya. Jurnal Manajemen Universitas Kristen Petra. 4(1), 376-386.

Torisa Utami, I. (2010). Pengaruh Gaya Kepemimpinan Transformasional Terhadap Motivasi Kerja Karyawan Pada PT Trade Servistama IndonesiaTangerang. Jurnal Akademi Sekretari Universitas Budi Luhur. 73. 73-81. doi.org/10.1080/09638180.2018.1509014

Tribun Bali.com. (2018). Penanganan Kasus Koperasi Bodong Rp 150 Miliar. RetrievedfromTribunBali.comwebsite:https:/ / bali.tribunnews.com/2019/0 $1 / 29 /$

Wardana, M. A. \& Dodik. A. (2016). Pengaruh Gaya Kepemimpinan Transformasional , Objektivitas, Integritas Dan Etika Auditor Terhadap Kualitas Audit. Skripsi. Fakultas Ekonomi dan Bisnis Universitas Udayana 948-976. doi.org/10.1506/car.26.2.2

Widyasari, H., \& Suardikha, I. M. S. (2015). Pengaruh Kemampuan Teknik Pemakai, Motivasi Kerja, Dukungan Manajemen Puncak, Lingkungan Kerja Fisik Pada Perilaku Etis Individual. E-Jurnal Akuntansi Universitas Udayana, 678-697. https://doi.org/10.24843/eja.2018.v24.i01.p03

Yukl, G., \& Hall, P. (2002). Leadership in Organizations. Journal ASA University Review. 4(2), pp: 50-56.

Yusuf, M. (2009). Pengaruh Komitmen Organisasi, Gaya Kepemimpinan, Motivasi Dan Perilaku Etis Sebagai Variabel Moderating Terhadap Hubungan Antara Partisipasi Penyusunan Anggaran dan Perilaku Etis Manajerial. Skripsi. Fakultas Ekonomi Dan Ilmu Sosial Universitas Islam Negeri Syarif Hidayatullah Jakarta. ISSN 2252-6765.

Zhu, W., May, D. R., \& Avolio, B. J. (2014). The Impact of Ethical Leadership Behavior on Employee Outcomes. International Journal of Applied Business and Economic Research, 13(6), 4283-4304. https://doi.org/10.1108/EBS-07-20120035 